\title{
Electronic Transcript Management System
}

\author{
Esite Jeremiah Tamarankuroemi \\ Student, University of Port Harcourt \\ Port Harcourt, Rivers State \\ Nigeria
}

\begin{abstract}
There has been a recent shift from manual to an automated approach for transcript management. A management system capable of result input and management as well as a system for graduates to make transcript requests from any internet enabled web browser. This approach is very much effective in transcript and result management for any higher institution within Nigeria operating a similar grading system to that of University of Port Harcourt. The current system for managing results has proven to be inefficient making it a necessity for a faster and efficient approach. Using modern web tools, a web-based transcript management system can be developed to solve the problems of the current system being used.
\end{abstract}

Keywords: Transcript, Web, Web-Based, Web Browser, MySQL

\section{INTRODUCTION}

Recent developments in Nigerian higher institutions have seen a rising need to automate transcript management. Several means of achieving this via a software-based approach exists.

Software can be simply referred to as "The programs, programming languages, and data that direct the operations of a computer system" [5].

Result processing can be seen as a continuous process of converting data (scores, grade points, credit units etc.) into a definite and meaningful information such as statement of result, transcripts etc. [1]. Students' performances are judged based on the outcome of their results. If an adequate result management and processing system is not in use, there could be problems which at the end would diminish the aim of which results and consequently transcripts were meant for.

A transcript is documentation of a student's permanent academic record, which usually means all courses taken, all grades received, all honours received, and degrees conferred to a student [6].

As students go through different educational processes to earn a degree, the need for the sending, processing and grading students using paper records become cumbersome and unmanageable.

Currently, sending and receiving paper transcripts remains the most common form of record transfer, even though labourintensive, manual keying of data must occur on both ends of the transaction [3]. A web-based electronic transcript management and processing system will help in reducing problems that stem from the manual means of processing. In this system, only authorized user(s) would have access to the system.

The web-based transcript management system meant for processing of the transcripts will be done using HTML5, CSS3 and jQuery for front end design, AJAX for interaction with PHP (Hypertext Pre-Processor) which is server side programming language and MySQLi (My Structural Query Language improved). The languages were chosen based on their flexibility and ease while working locally using a XAMPP server.

With proper programming practices, students' Grade Point Average (GPA) and Cumulative Grade Point Average (CGPA) can be calculated on computation of the necessary data.

\section{CURRENT MANUAL APPROACH}

In most Nigerian higher institutions, result management is the duty of the Exams and Records administrative department of the school.

Each department also have copies of every student's result. In processing a student's transcript using University of Port Harcourt as a case study, the following steps are taken as presented in the block diagram of fig. 1.

Firstly, payment is made to a designated bank account. This amount is dependent on the transcript delivery destination. After the payment has been made, the student then goes to the Exams and Records department with a formal letter requesting for his academic transcript. The letter is forwarded to the student's department requesting for copies of his results. These copies are then sent back to the Exams and Records office for compilation and then sent to the office of the Registrar where it is signed and sent back to the Exams and Records office. The transcript is then sealed and sent to the stipulated address through a courier service.

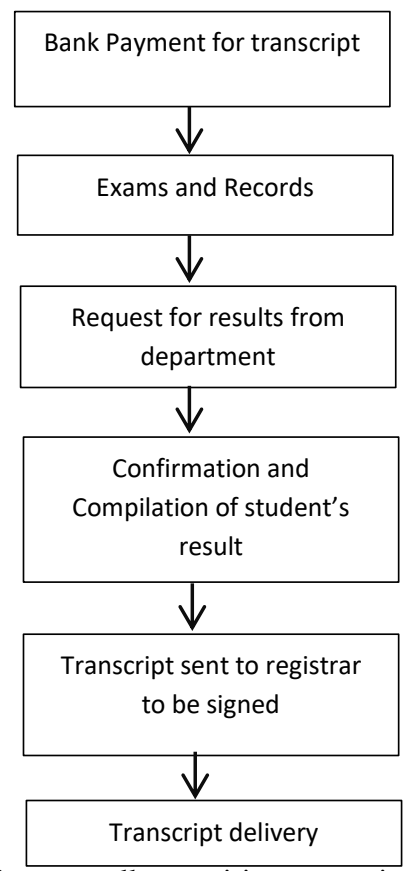

Fig. 1: Steps for manually acquiring transcript in University of Port Harcourt 
This method is slow, error-prone and stressful. These problems can be diminished by making use of a computer based processing system or an electronic transcript management system [4].

\section{WEB-BASED APPROACH OF TRASCRIPT MANAGEMENT}

Steps have been taken towards automation of transcript management with the use of excel spread sheet. Here, the programming is hard coded into the cells, and cell referencing which could be applied to monitor and track students' performances such as cumulative points [2].

In this paper, a web-based system of database management of transcript is our primary focus. MySQL database is made use of. The database is structured in such a way that it allows for proper storage of useful student and staff date. This approach, though tested and found to be working as expected, has however not been put to use widely [7].

Three access levels will be considered to allow for the success of this approach: Administrator, Student and Lecturer access levels. These three levels of access will be powered by the content of their database tables.

Administrator Access Level: The administrator (admin) has complete access and control of other users. The administrator can access the following tables in the database:

Students' personal details: This table contains students' matriculation number and other personal information. Each student can then access their individual portals by making use of their matriculation number and password. Changes can be made to their personal details only by the administrator.

\begin{tabular}{|c|c|c|c|c|c|c|c|}
\hline & $\#$ & Name & Type & Collation & Attributes & Null & Default \\
\hline 回 & 1 & id & $\operatorname{int}(11)$ & & & No & None \\
\hline$\square$ & 2 & fullname & $\operatorname{int}(11)$ & & & No & None \\
\hline 回 & 3 & mat_number & $\operatorname{int}(11)$ & & & No & None \\
\hline$\square$ & 4 & faculty & $\operatorname{varchar(11)}$ & latin1_swedish_ci & & No & None \\
\hline$\square$ & 5 & department & $\operatorname{varchar(11)}$ & latin1_swedish_ci & & No & None \\
\hline$\square$ & 6 & level & $\operatorname{varchar}(11)$ & latin1_swedish_ci & & No & None \\
\hline$\square$ & 7 & password & $\operatorname{varchar}(11)$ & latin1_swedish_ci & & No & None \\
\hline$\square$ & 8 & status & $\operatorname{varchar(11)}$ & latin1_swedish_ci & & No & None \\
\hline 回 & 9 & date & date & & & No & None \\
\hline$\square$ & 10 & time & time & & & No & None \\
\hline
\end{tabular}

Fig. 2: Students user accounts on the MySQL database

Lecturers' personal details: Personal accounts of lecturers can be created by the administrator which will include the course the lecturer would take for that semester. The information that will be contained in the database for each lecturer can be represented as seen in fig. 3 .

\begin{tabular}{|c|c|c|c|c|c|c|c|}
\hline & \# & Name & Type & Collation & Attributes & Null & Default \\
\hline$\square$ & 1 & id & $\operatorname{int}(11)$ & & & No & None \\
\hline$\square$ & 2 & fullname & $\operatorname{varchar}(30)$ & latin1_swedish_ci & & No & None \\
\hline 回 & 3 & web_mail & varchar(11) & latin1_swedish_ci & & No & None \\
\hline$\square$ & 4 & faculty & varchar(11) & latin1_swedish_ci & & No & None \\
\hline$\square$ & 5 & department & varchar(11) & latin1_swedish_ci & & No & None \\
\hline$\square$ & 6 & password & $\operatorname{varchar}(20)$ & latin1_swedish_ci & & No & None \\
\hline$\square$ & 7 & date & date & & & No & None \\
\hline$\square$ & 8 & time & time & & & No & None \\
\hline
\end{tabular}

Fig. 3: MySQL database showing the structure of the lecturers' user accounts table

List of all courses: All courses available in the school will also be registered into the database by the administrator.

\begin{tabular}{|c|c|c|c|c|c|c|c|}
\hline & $\#$ & Name & Type & Collation & Attributes & Null & Default \\
\hline 回 & 1 & id & $\operatorname{int}(11)$ & & & No & None \\
\hline$\square$ & 2 & course_name & $\operatorname{varchar}(20)$ & latin1_swedish_ci & & No & None \\
\hline 回 & 3 & course_code & $\operatorname{varchar(11)}$ & latin1_swedish_ci & & No & None \\
\hline$\square$ & 4 & course_unit & $\operatorname{int}(11)$ & & & No & None \\
\hline 回 & 5 & level & int(11) & & & No & None \\
\hline$\square$ & 6 & faculty & $\operatorname{varchar(11)}$ & latin1_swedish_ci & & No & None \\
\hline 回 & 7 & department & $\operatorname{varchar}(11)$ & latin1_swedish_ci & & No & None \\
\hline 回 & 8 & date & date & & & No & None \\
\hline$\square$ & 9 & time & time & & & No & None \\
\hline
\end{tabular}

Fig. 4: MySQL database showing the structure of the list of courses

Lecturers' courses: Every semester, each lecturer is set to teach a particular course which has to be updated by the administrator. This information is updated in the MySQL database and can is represented as seen in fig. 5. Each lecturer can only input results of student for courses he currently handles.

\begin{tabular}{|c|c|c|c|c|c|c|}
\hline & \# & Name & Type & Collation Attributes & Null & Default \\
\hline$\square$ & 1 & id & $\operatorname{int}(11)$ & & No & None \\
\hline$\square$ & 2 & course_id & int(11) & & No & None \\
\hline$\square$ & 3 & lecturer_id & $\operatorname{int}(11)$ & & No & None \\
\hline$\square$ & 4 & date & date & & No & None \\
\hline$\square$ & 5 & time & time & & No & None \\
\hline
\end{tabular}

Fig 5: MySQL database showing the structure of the courselecturer table

Transcript requests: When requests for transcripts are made by students, the administrator changes the status of the request to show if it was granted or not as well as the stages of processing it has reached. 


\begin{tabular}{|c|c|c|c|c|c|c|c|}
\hline & $\#$ & Name & Type & Collation & Attributes & Null & Default Extra \\
\hline 回 & 1 & id & $\operatorname{int}(11)$ & & & No & None \\
\hline$\square$ & 2 & student_id & int(11) & & & No & None \\
\hline 回 & 3 & request_status & $\operatorname{varchar}(11)$ & latin1_swedish_ci & & No & None \\
\hline$\square$ & 4 & remark & varchar(11) & latin1_swedish_ci & & No & None \\
\hline 回 & 5 & date & date & & & No & None \\
\hline$\square$ & 6 & time & time & & & No & None \\
\hline
\end{tabular}

Fig 6: MySQL database showing the structure of the transcript request table

Student Access Level: The student portal allows the user to login to his personal account in order to make register for semester courses, view results and make requests for a transcript.

The courses registered will then be filled with their appropriate scores by the corresponding course lecturer.

\begin{tabular}{|c|c|c|c|c|c|c|c|}
\hline & $\#$ & Name & Type & Collation & Attributes & Null & Default Extra \\
\hline 回 & 1 & id & $\operatorname{int}(11)$ & & & No & None \\
\hline 回 & 2 & course_id & int(11) & & & No & None \\
\hline$\square$ & 3 & mat_number & varchar(11) & ) latin1_swedish_ci & & No & None \\
\hline$\square$ & 4 & school_session & varchar(11) & ) latin1_swedish_ci & & No & None \\
\hline 回 & 5 & semester & varchar(11) & ) latin1_swedish_ci & & No & None \\
\hline$\square$ & 6 & level & varchar(11) & ) latin1_swedish_ci & & No & None \\
\hline 回 & 7 & date & date & & & No & None \\
\hline$\square$ & 8 & time & time & & & No & None \\
\hline
\end{tabular}

Fig 7: Structure of the course registration on MySQL database table.

With this, every student can register a course once a school session resumes and it will also determine the courses for which the student can be assessed by the lecturer.

Lecturer Access Level: The lecturer's portal is set aside for inputting the result for the course(s) he currently takes. The lecturer can only input scores for students who registered for his course. The score input for a course is represented in fig. 8 .

\begin{tabular}{|c|c|c|c|c|c|c|c|}
\hline & \# & Name & Type & Collation & Attributes & Null & Default \\
\hline 回 & 1 & id & $\operatorname{int}(11)$ & & & No & None \\
\hline$\square$ & 2 & course_id & $\operatorname{int}(11)$ & & & No & None \\
\hline 回 & 3 & course_unit & $\operatorname{int}(11)$ & & & No & None \\
\hline 回 & 4 & mat_number & varchar(11) & latin1_swedish_ci & & No & None \\
\hline 回 & 5 & school_session & $\operatorname{varchar}(11)$ & latin1_swedish_ci & & No & None \\
\hline$\square$ & 6 & semester & varchar(20) & latin1_swedish_ci & & No & None \\
\hline 回 & 7 & lecturer_name & varchar(11) & latin1_swedish_ci & & No & None \\
\hline 回 & 8 & score & $\operatorname{int}(11)$ & & & No & None \\
\hline 回 & 9 & grade & varchar(11) & latin1_swedish_ci & & No & None \\
\hline$\square$ & 10 & date & date & & & No & None \\
\hline 回 & 11 & time & time & & & No & None \\
\hline
\end{tabular}

Fig. 8: MySQL database table meant for inserting courses and their grades for different students who registered for that course.

From fig. 8, scores for a particular course are stored in the results database table which includes the matriculation number, course id, semester the course belongs to as well as the session, lecturer's name, total score, and grade.

Fig. 9 shows an implementation of the tables in the MySQL database using a local host called XAMPP. In the database, tables have been created for specific records as seen in fig. 2-8. Each column is given a name and a data type allowing one to set any one of the column name as primary key. For this work, our primary key is the 'id'. As seen in fig. 9, each data table can be emptied or dropped. For the purpose of this work, a total of seven tables are required.

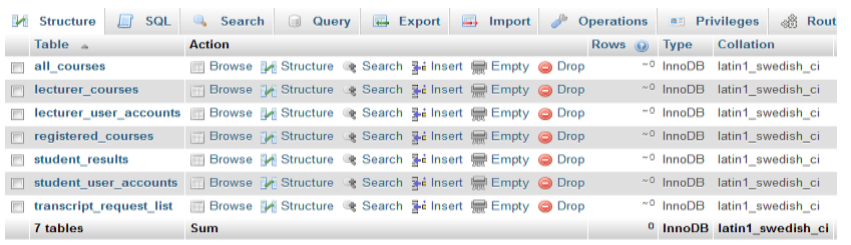

Fig. 9: MySQL database showing the different tables from localhost using XAMPP

Every account listed - administrator, lecturer and student - can be accessed by a user through the flow diagram shown in fig. 10 .

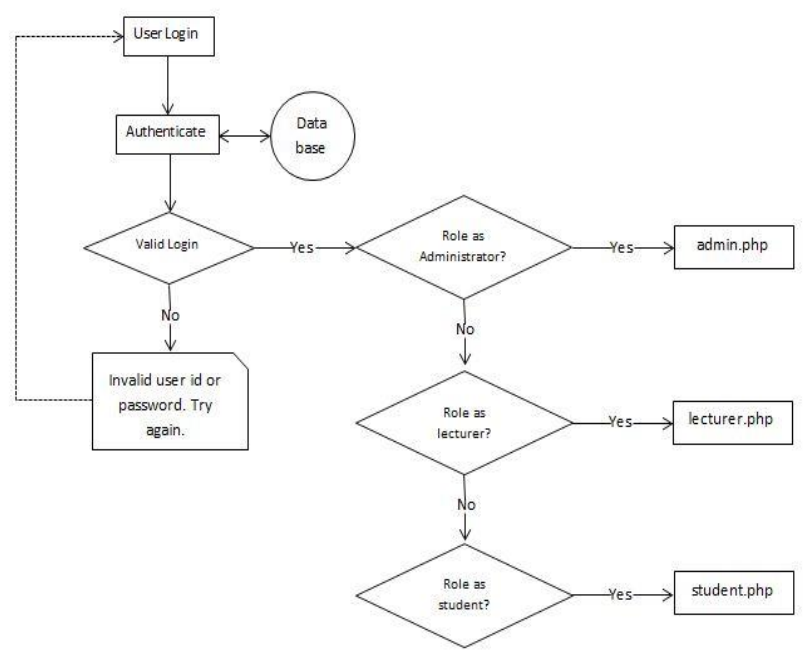

Fig. 10: Flow diagram for logging into the Transcript Management System (TMS)

\section{GRADE POINT AVERAGE (GPA) AND CUMULATIVE CGPA GRADE POINT AVERAGE CALCULATIONS}

For a given semester, each student would have a GPA while a combination of all available semester course assessments produces a CGPA.

Necessary information for calculating the semester GPA is available in the results table where the scores and their units are stored. The GPA for a semester is calculated using (1).

$G P A=$

Sum of total available scores for that semester sum of all units offered for the semester

For CGPA calculation, we make use of (2). 
$C G P A=\frac{\text { Sum of total available scores ever taken }}{\text { sum of all units offered }}$

(2)

\section{REQUEST FOR TRANSCRIPT}

In requesting for a transcript, a student logs into his account and selects the purpose for which the transcript is meant for in terms of delivery recipient. This could be a personal copy, for foreign institution or a Nigerian institution. This will determine the cost that will be paid by the student for the whole process.

Transcript request by students is shown by the following flow diagram in fig. 11.

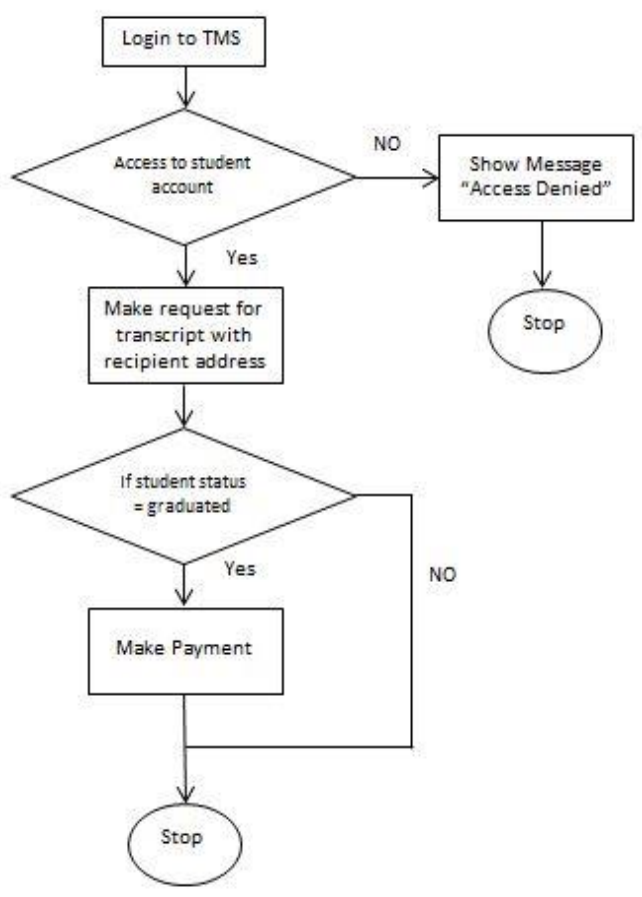

Fig. 11: Flow diagram for student's request for academic transcript

When a request is made by a student for a transcript, it is added to the request table which can be accessed only by the administrator. Here the administrator makes checks for those requests where payment has already been made and prints out the result by clicking on a print command button. This printed document is then sent to the Dean of Student Affairs for his signature. Once this is done, the transcript is then sealed and sent via courier service to the designated address. During this entire procedure, the administrator updates the status of the whole process so the student can view from his personal page.

The processing of the transcript can be summarised by the flow diagram in fig. 12 .

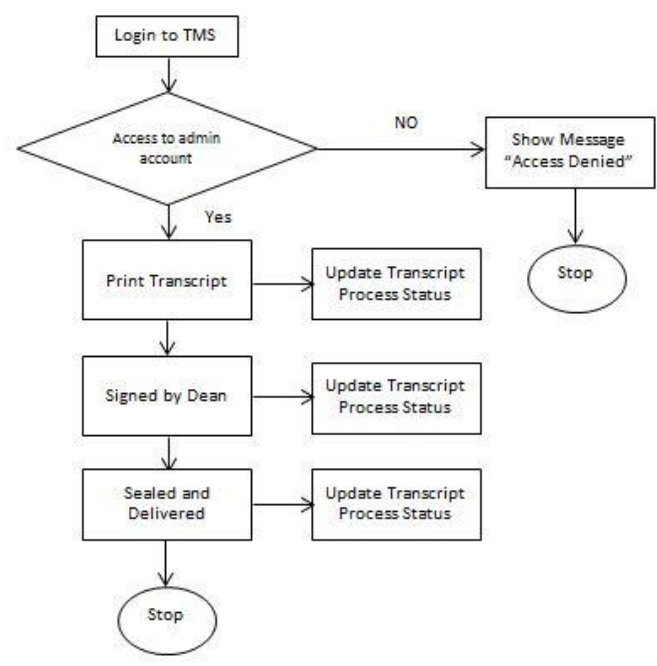

Fig. 12: Flow diagram for administrator processing of academic transcript

With each stage of processing, the administrator updates the status of that transcript request made by the student. This continues until the transcript is delivered to the recipient address.

\section{CONCLUSION}

An electronic transcript management system creates an avenue for information management to be convenient, efficient and easy to use. The application will be capable of storing and retrieving academic records with high speed and accuracy, and presenting useful information to its users.

The system provides an efficient means of processing, preserving and displaying students' results, academic records and other relevant notices to students. As part of its benefits, it is stress-free and speed-up the processing of students' examination results. Finally, the system is flexible and runs on a web browser. With this application, the processing of students' results is automated, thereby reducing processing time and increasing accuracy.

\section{REFERENCES}

[1] Dada, O. M., Rajii, A. K., \& Oyedepo, F. S. (2017). An Online Result Processing and Transcript Generation System: A Case Study of Kwara State Polytechnic. Tetfund Sponsored Kwara State Polytechnic Journal of Research and Development Studies Vol. 5. No. 1.

[2] Ekpenyong, M. E. (2008). A Real-Time IKBS for students' results computation. International Journal of Physical Sciences (Ultra Scientist of Physical Sciences), Vol. 20, No. 3.

[3] Kilgore, W., Gretchen, H., \& Matthew, H. (2014). Transcript Practices and Cost at U.S. Institutions. Washington, D.C: AACRO.

[4] Okonigene, R. E., Ighalo, G. I., \& E. Ogbeifun. (2008). Developed personal record software. The Pacific Journal of Science and Technology, http://www.akamaiuniversity.us/PJST.htm. 9(2):407-412.

[5] Software. (2019, January 20). Retrieved from: https://www.dictionary.com/browse/software 
International Journal of Science and Engineering Applications

Volume 8-Issue 10,461-465, 2019, ISSN:-2319-7560

[6] Transcript. (2019, January 22) Retrieved from http://www.lbwcc.edu/Content/Uploads/lbwcc.edu/files/Transcript s.pdf

[7] Ukem, E. O., \& Onoyom-Ita, E. O. (2011). A Software application for the processing of students results. Global Journal of Pure and Applied Sciences, Vol. 17 No. 4 